\title{
Montenegro's Strategic Priorities on the Path of Euro-Atlantic Integration
}

\author{
Gordana Djurović *
}

\begin{abstract}
Euro-Atlantic integration is the best framework for ensuring the long-term stability and security of the countries in the Western Balkans, and is the precondition for their economic development. Euro-Atlantic frameworks provide mechanisms for establishing confidence between countries in the regions, as well as strengthening cooperation and understanding, in the area of security and in many other fields. This is the reason why Montenegro fully supports the Euro-Atlantic aspirations of its neighbors, with a focus on regional cooperation and participation in all regional initiatives that are based on a good-neighbor policy. Montenegro's strategic priorities on the international level are building positive relations with its neighbors, increasing the level of regional security, and contributing to peacekeeping and stability in the world through participation in international missions and operations led by the UN, the EU, and NATO. At the same time, practical and efficient realization and implementation of a range of Partnership for Peace mechanisms have enabled Montenegro to gain access in a very short period of time to the Intensified Dialogue with NATO, and to begin the initial stages of the Membership Action Plan. Montenegro is ready to respond as rapidly as possible to all challenges that might arise in its path toward NATO membership, and looks forward to working in consultation and assistance with NATO, its neighbors, and other member states of NATO and the PfP.
\end{abstract}

\section{Introduction}

The primary goal of each country participating in the Euro-Atlantic integration process on the path to full NATO membership is to become a formal member of the Alliance. But this goal is supported by a number of other goals related to undertaking the necessary reforms in order to achieve the expected level of interoperability of its own security forces with those of other NATO members, thus enabling the aspirant countries to participate in joint peace activities and contribute to international stability and security.

Achieving the required level of interoperability affects not only the security system within an aspirant nation (primarily the defense sector), but also a range of other state organizational structures that have an impact on institutional interoperability, given that they influence the structure and function of the nation's security system. How a state achieves these goals and how long it takes will be different for each country, which is reflected primarily in its overall capabilities and identified requirements.

After gaining independence in May 2006, Montenegro began a new process of building its society - a process that, through the mechanisms of Euro-Atlantic integration, will ultimately lead to membership in NATO and the EU. After joining the Partnership for Peace (PfP) in November 2006, Montenegro began to implement the PfP

Prof. Gordana Djurović, Ph.D., is Montenegro's Minister for European Integration and a full-time professor at the Faculty of Economics in Podgorica. From 2005-07, she was the head of Montenegro's negotiating team for the EU's Stabilization and Association Process. 
mechanisms for security sector reform that are a requirement of eventual accession to NATO membership. ${ }^{1}$ Developing good relations and pursuing cooperation with the countries in its immediate vicinity (three of which - Slovenia, Croatia, and Albaniaare already NATO members), Montenegro contributes to the increase of stability and peace in the Western Balkans. This article will provide an overview of the status of the process of Montenegro's accession to NATO membership at the moment of having been approved as a candidate for participation in NATO's Membership Action Plan (MAP), along with a review of what has been achieved up to this point and what is still necessary to be done on the road to NATO membership in the near future.

\section{Montenegro's Results in the Euro-Atlantic Integration Arena}

The results that Montenegro has achieved in the area of Euro-Atlantic integration are best reflected in the successful fulfillment of the obligations that stem from PfP documents and mechanisms that have been assembled by Montenegro in cooperation with NATO. These mechanisms, which will be outlined below, have led to Montenegro's admission into the Membership Action Plan.

\section{Mechanisms of Montenegro's Participation in the Partnership for Peace}

The mechanisms involved in becoming a member of the Partnership for Peace represent an organized system of relations between the Partner states and NATO in the process of achieving common goals. ${ }^{2}$ Through the Framework Document, which is signed with NATO, each country commits to engaging in the achievement of these common goals, according to established PfP procedures. How the goals that are specific to each state will be achieved depends in part on the goals and fields of cooperation that the state sets forth in its Presentation Document. ${ }^{3}$ From the moment of entering the Partnership for Peace, Montenegro has been, together with NATO, involved in the implementation phase of four cooperation mechanisms: the Individual Partnership Program (IPP); the Planning and Review Process (PARP); the Individual Partnership Action Plan (IPAP); and the Intensified Dialogue (ID).

1 Montenegro was invited to join the PfP at the NATO Summit in Riga on 29 November 2006. The signing of the Partnership for Peace Framework Document followed on 14 December 2006, and the submission of the Presentation Document of Montenegro on 25 April 2007. Parallel to the submission of the Presentation Document, the Agreement on Data Security between Montenegro and NATO was signed.

2 Mehmedin Tahirovic, "Montenegro and the NATO Partnership for Peace Program," Connections: The Quarterly Journal 7:1 (Spring 2008); available at https://consortium.pims.org/ tags/mehmedin-tahirovic.

3 In order to ensure the effective fulfillment of the obligations that it assumed through the Presentation Document, Montenegro established the PfP Council, as well as a Commission for Inter-Agency Activities of Montenegro in PfP on 28 December 2006. After adopting the new constitution in October 2007, in November of the same year Montenegro established its Council for Defense and Security. 
Individual Partnership Program. The Individual Partnership Program (IPP) is a bilateral agreement between a Partner state and NATO that regulates the joint execution of chosen activities from the Euro-Atlantic Partnership Work Plan (EAPWP). These activities can include efforts in the areas of education, civil-military relations, crisis management, communications and information systems, airspace protection, etc. All member states and Partners, in cooperation with NATO, select activities that they consider the most useful in the process of adapting their defense systems to NATO requirements in accordance with the goals set forth in the Presentation Document. During the preparation and implementation of the IPP, the ePRIME electronic program (Electronic Partnership Real-time Information Management and Exchange System) is used via the Internet.

The first Montenegrin IPP was made in October 2007, and was accepted by NATO in January 2008. According to this plan, during 2008 Montenegro was to participate in nearly seventy specific activities, focused on the following priorities: foreign language education, medical support, military education, training, and military doctrine. After a round of consultations with NATO, the IPP activities for 2008 were revised, so that the total number of activities was reduced to forty-eight, in order to be more realistically in line with Montenegro's capabilities and capacities. In January 2009, the annual analysis of the implementation of IPP for 2008 showed that Montenegro had succeeded in executing 71 percent of the activities it had agreed to pursue. The final harmonization meeting for IPP for the year 2010 was held in Brussels on 9 December 2009, where forty-nine activities were defined for Montenegro, involving seventy-eight participants.

Planning and Review Process. The Planning and Review Process (PARP) presents one of the key mechanisms of the Partnership for Peace. PARP enables the Partners to develop their capabilities in order to satisfy their security needs and make a contribution to NATO operations. By participating in the Planning and Review Process, Partner states set certain requirements for themselves in the development of their capabilities through the establishment of Partnership Goals that they want to achieve.

The Partner states make their commitments based on free choice, on the stipulations of a Presentation Document, or on subsequent political decisions about the content of their respective PARP. In September 2007, Montenegro handed over the responses to the first PARP Questionnaire, the results of which were presented on 31 March 2008 in Brussels, where thirty-two Partnership Goals were also set for Montenegro (with priority placed on foreign language education and the preparation of military units for participation in international forces). ${ }^{4}$ In June 2008, Montenegro received

4 Partnership Goals are defined for a two-year period. Montenegro chose thirty-two Partnership Goals (in conjunction with NATO) for 2008. The new package of Partnership Goals will be accepted in 2010 (a portion of the Partnership Goals will be the same, because many of them are either long-term goals or permanent results, such as learning foreign languages, but some of the goals will be new). 
the second PARP Questionnaire, and responses to which were submitted to NATO on 29 September 2008. These results were ratified in Brussels on 16 February $2009 .{ }^{5}$

Individual Partnership Action Plan. The Individual Partnership Action Plan (IPAP) was initiated in November 2002, at the NATO Summit in Prague. The IPAP enables the Alliance to put together programs of assistance for Partner countries that require more structured aid in implementing national reforms, according to their specific needs and circumstances. At the next NATO Summit, in Istanbul in 2004, the mechanisms of the Individual Partnership Action Plans were elaborated in even greater depth, and the process was adapted to the PfP members, so that they may execute their reforms with even greater success. The IPAP process is intended for the Partner countries, and enables the reform and modernization of their security sectors and improves their level of cooperation with NATO.

In December 2007, the government of Montenegro adopted the Information on the Accession of Montenegro to IPAP, and NATO approved the start of IPAP for Montenegro on 5 February 2008. The IPAP Presentation Document was submitted on 11 March $2008,{ }^{6}$ after which date the process of reporting on IPAP implementation began. ${ }^{7}$ IPAP anticipates the accomplishment of 167 activities; 31 of those activities have been scheduled for $2008,{ }^{8}$ and the other 136 activities are planned to be accomplished over a course of several years.

Intensified Dialogue. Based on the provisions of the 1995 Study on NATO Enlargement, the Intensified Dialogue is conducted in the form of meetings between the North Atlantic Council and high representatives of aspiring member countries (prime ministers, ministers of foreign affairs, and defense ministers) regarding the issues related to the respective states' accession to NATO. The goal of the Intensified Dialogue is to help the aspirant country to define the areas where it is necessary to harmonize its structures and formulate common recommendations for reaching interoperability. Therefore, these meetings are used to discuss political, military, financial, and security issues concerning the country's future membership in NATO. After the establishment of the MAP process in 1999, all of the countries that had participated in the Intensified Dialogue up to that point were automatically admitted to the MAP proc-

5 For the purpose of harmonizing the answers to the PARP Questionnaire, a NATO expert team visited Montenegro, from 26-29 January 2009.

6 The Montenegrin Ministers of International Affairs and Defense submitted the Presentation Document and IPAP at the Meeting of the NATO High Political Committee at the level of Deputy Chiefs of Missions.

7 The first IPAP was submitted to NATO on 24 June 2008, and was accepted on 1 July 2008. It was the first joint document between Montenegro and NATO. The government accepted the first report on the implementation of IPAP on 18 December 2008. The second report covered the first six-month period of 2009, and was accepted at the meeting of Montenegro's Council for the Partnership for Peace on 24 July 2009.

8 At present, twenty-five out of the thirty-one activities for 2008 have been completed, which makes for a total of eighty, or 64 percent of the total number that were scheduled. 
ess, which was presented as its upgrade. ${ }^{9}$ Intensified Dialogue (ID) and IPAP are mechanisms that proceed simultaneously. ID represents the final preparation for arriving at candidate status for membership in NATO, i.e., the start of the Membership Action Plan.

Montenegro officially expressed its interest in initiating the ID process with NATO on 11 January 2008; at the NATO Summit in Bucharest, on 3 April 2008, Montenegro was invited officially to start the ID process. The Council of the PfP adopted the initial document for Montenegro's ID discussion in June 2008, after which date the implementation phase started (consisting of thematic meetings ${ }^{10}$ in the areas encompassed in the ID). ${ }^{11}$ Montenegro officially completed the ID cycle in January 2009.

\section{Strategic Documents and Laws}

It must be borne in mind that the majority of Montenegrin strategic documents, laws, and regulatory documents have been inherited from the state union of Serbia and Montenegro, and that their contents were not compatible with the new direction in the development of Montenegrin society after the renewal of independence. As a result, it was necessary to begin making completely new ones, which would provide the country with the legal and regulatory framework that would permit the unobstructed and effective accomplishment of the goals that had been set forth as part of the broader EuroAtlantic integration process.

Membership in the EU and NATO had been set out as a strategic goal in the fundamental Montenegrin documents, such as the Constitution of Montenegro, ${ }^{12}$ the Declaration of Accession to the European Union, ${ }^{13}$ and the Declaration of Independence of the Republic of Montenegro. ${ }^{14}$ In order to accelerate the processes of European and Euro-Atlantic integration, a resolution on the necessity of speeding up the integra-

9 See "Membership Action Plan," in the NATO Handbook 2006 (Brussels: NATO, 2006).

10 The following meetings were held regarding the ID: a plenary meeting for the Intensified Dialogue between the representatives of Montenegro and NATO, held at NATO HQ in Brussels on 24 June 2008; the ID meeting on defense and security issues between Montenegrin and NATO representatives, 4 September 2008; ID meeting on the implementation of the communication strategy on Euro-Atlantic integration, 20 January 2009; two ID-specific dedicated meetings on security and protection of classified data and on legal issues, 27 January 2009.

11 The Intensified Dialogue (ID) document consists of the following six fields: Montenegro and NATO Enlargement; Political Framework; International and Security Policy of Montenegro; Defense and Military Issues; Economy; and Future Steps.

12 The Constitution of Montenegro, Official Gazette of Montenegro, no. 01/07 (25 October 2007); available at www.sllrcg.cg.yu/001-2007.pdf.

13 The Declaration on Accession to the European Union, Official Gazette of Montenegro, no. 36/05 (16 June 2005).

14 The Declaration of the Independent Republic of Montenegro, Official Gazette of Montenegro, no. 36/06 (5 June 2006). 
tion processes was passed on 3 October 2008. ${ }^{15}$ According to the Constitution of Montenegro, the Parliament is required to adopt the National Security Strategy and the Defense Strategy, ${ }^{16}$ which it did on 27 November $2008{ }^{17}$ and 18 December 2008, respectively. ${ }^{18}$

The Law on Defense ${ }^{19}$ and the Law on the Military were adopted ${ }^{20}$ in August 2007. After the adoption of the constitution, it was necessary to harmonize the aforementioned documents with the new constitution, and therefore, on 18 December 2008, the Montenegrin government proposed changes and additions to the Law on Defense and the Law on the Military. According to the proposal of the Defense and Security Council, these laws were submitted under a procedure that allowed the government to propose changes after a year. Thus, at the session of parliament on 3 December 2009, the government set forth a new law proposing changes and additions to the Law on Defense and the Law on the Military, which was taken under review by the parliament for adoption. Also currently ongoing is the drafting of the Strategic Defense Review, which is the fundamental document that will provide answers regarding the capabilities and requirements of the development of Montenegro's defense systems.

\section{Establishment of the Mission to NATO in Brussels and the Military- Diplomatic Network in Montenegro}

The creation of a favorable international climate in the process of integrating Montenegro into the Euro-Atlantic security community is one of the most important conditions for its successful completion. With the goal of increasing the level and quality of cooperation, maintaining continuous communication with NATO, and of coordinating activities with respect to the nation's obligations in PfP, in June 2007 Montenegro established a diplomatic mission to NATO Headquarters in Brussels. The mission consists of three sections: political, military, and defense. Each of these sections has a clearly defined role, which is accomplished through daily communication with the various specialized structures within NATO. The mission representatives, within the scope of their responsibilities, participate in the work of NATO management authorities. The structure of the mission is defined by the various national regulations on the

15 "Resolution on the necessity of accelerating the process of integration of Montenegro into the European and Euro-Atlantic structures," Official Gazette of Montenegro, no. 60/08 (9 October 2008).

16 Article 82, point 6 of the Constitution of Montenegro.

17 National Security Strategy, Official Gazette of Montenegro, no. 75/08 (8 December 2008). The first National Security Strategy of Montenegro was adopted in June 2006, immediately after the country gained independence, due to the need to start the Euro-Atlantic integration process. But after the new constitution was adopted, in 2007, a new strategy was developed in order to adjust it to the provisions of the new constitution.

18 The Defense Strategy of Montenegro, Official Gazette of Montenegro, no. 79/08 (23 December 2008).

19 The Law on Defense, Official Gazette of Montenegro, no. 47/07 (7 August 2007).

20 The Law on the Military of Montenegro, Official Gazette of Montenegro, no. 47/07 (7 August 2007). 
organization of work positions. The political unit is subject to the Regulation on the Operation of Diplomatic Representation Abroad of 2008; the military and defense sections are regulated by a special statute on the internal organization of the Ministry of Defense. ${ }^{21}$

As of June 2009, four people were engaged in the political section, two in the military section, and one in the defense section. Apart from these mission staff, one liaison officer is engaged in the MCD (Military Cooperation Division) in Mons, and one liaison officer and one staff member in the PSE (Partner Staff Element) in JFC, Naples.

In order to improve the level of bilateral defense cooperation, Montenegro has also started establishing a military-diplomatic network. At this point, four military attachés from Montenegro have been accredited in the following countries: Slovenia, Austria (at the same time covering the post of the military representative to the OSCE), the United States, and Germany.

\section{Agreements Between NATO and Montenegro}

Montenegro, like most of the PfP member countries, signed two agreements related to the establishment of conditions for the unhindered transit of armed forces over its territory: the Agreement on the Transit of NATO Forces in Support of Peace Operations (signed 26 November 2007) and the Agreement on the Transit of the EU Forces (EUFOR) over the Territory of Montenegro (signed 7 May 2007). These pacts represent the continuation of the implementation of agreements that had been previously signed under the State Union of Serbia and Montenegro, before Montenegro regained its independence. ${ }^{22}$ In order to regulate the status of foreign forces in Montenegro and the status of Montenegrin forces abroad, Status of Forces Agreements (SOFA) have been signed with the U.S. (on 2 May 2007) and NATO/PfP (14 December 2008). ${ }^{23}$

Montenegro signed the Agreement on Information Security with NATO on 25 April 2007. Less than a year later, in February 2008, the Parliament of Montenegro adopted the Law on Classified Information, ${ }^{24}$ and in April 2008 the Directorate for the Protection of Classified Information was established. ${ }^{25}$ Representatives of the NATO

21 Act on the Internal Organization and Systematization of the Ministry of Defense, the Government of Montenegro, Podgorica, 13 November 2008.

22 The Agreement on Transit Arrangements in Support of Peace Operations between Serbia and Montenegro was signed in Belgrade on 18 July 2005.

23 At the ceremony held at the U.S. State Department on 14 December 2008, the Montenegrin Ambassador to the U.S., Miodrag Vlahovic, signed the NATO PfP Agreement on Status of Forces (SOFA). This agreement provides adequate protection to the Montenegrin Armed Forces in other NATO and PfP countries. Montenegro's main obligation under the agreement is to provide the same protection to the NATO and PfP forces in Montenegro. Apart from that, this agreement enables the conduct of joint military exercises and training.

24 The Law on Protection of Classified Information, Official Gazette of Montenegro, no 14/08 (29 February 2008).

25 The Directorate for the Protection of Classified Information is listed in the document "Regulation on the Organization and Operation of the State Administration," Official Gazette of Montenegro, no. 54/04 (9 August 2004) and no. 43/09 (3 July 2009). 
Security Office paid a visit to the Directorate for the Protection of Classified Information in November 2008 and, based on their report, NATO certified the Agreement on Information Security with Montenegro on 17 November 2008. This agreement gave Montenegro the ability to work with NATO documents classified up to the level of "Secret." With respect to the provision of support as a host country for NATO exercises and operations on the territory of Montenegro, on 29 June 2009 the Montenegrin government accepted a Memorandum of Understanding with NATO, which was ratified later that year. ${ }^{26}$

\section{Montenegro's Participation in NATO Scientific Programs}

Since February 2007, Montenegro has been a full member of the NATO SPS program (Science for Peace and Security). Montenegro is currently providing the biggest contribution to a three-year regional project called "The Harmonization of Maps of Seismological Hazards in the Western Balkans," which is being implemented under the coordination of the Seismologic Agency in Montenegro. This project brings together (apart from NATO) regional experts from Albania, Bosnia \& Herzegovina, Croatia, Macedonia, Serbia, and NATO member states, including Turkey, Greece, and Slovenia.

\section{Montenegro's Accession to the Membership Action Plan ${ }^{27}$}

As a result of its work towards the fulfillment of the obligations that it accepted through the PfP membership mechanisms, and the reforms it has already implemented in the security sector, Montenegro established the necessary conditions to enable it to enter into the next phase of relations with NATO, the Membership Action Plan (MAP), which allows a state to become an indirect candidate for NATO membership. MAP allows for all of the activities that a Partner country is carrying out within the EuroAtlantic integration process to be combined into a single action plan guided by NATO. Montenegro was invited to join the MAP process at the meeting of the ministers of foreign affairs of NATO member states held on 4 December 2009 in Brussels.

\section{Montenegro's Contribution to International Peace and Stability}

Montenegro is strategically committed to improving regional cooperation and contributing to the balance of peace and stability in the world. Through its active engagement, Montenegro hopes to exert a positive influence on the level of security in the Western Balkans. Unlike most of the countries that (unfortunately) gained their independence through war after the dissolution of the Social Federal Republic of Yugoslavia, Montenegro gained its independence in a democratic way, following some fairly unusual

26 The Conclusion of the Government of Montenegro, No. 03-8643 (29 June 2009). The signing of this document will enable the organization of three NATO exercises in Montenegro, all planned for 2010: "Cooperative MARLIN," "Cooperative MAKO," and "MEDCEUR."

27 The MAP process was created out of the necessity to expand NATO membership to include former communist countries, in accordance with Article 10 of the Washington Treaty from 1999. 
standards that had been defined by the European Union. It was necessary that 55 percent of the citizens of Montenegro vote for independence, which was a new requirement among European democratic standards, but at the same time it represented a new democratic value in the region. As it has entered into the Euro-Atlantic integration process, Montenegro is able to make the following claims:

- Montenegro does not have any unresolved territorial issues with its neighbors (border disputes or territorial ambitions) ${ }^{28}$

- The position and balance of minorities and ethnic groups in Montenegro is satisfactory, with the prospect of their rights being adequately resolved according to European standards

- Montenegro has good relations with all of its neighbors in the region; it has signed the Agreements on Cooperation with most of them, ${ }^{29}$ and is involved in several regional initiatives and cooperation processes

- Montenegro is a highly desirable tourist destination in Europe and, apart from other advantages that are very important and characteristic of the Western Balkans region, it is convenient for the organization of various international conferences and meetings.

\section{Regional Cooperation Initiatives}

The events that marked the dissolution of the former Yugoslavia provided for a practical test of cooperation between NATO and the Partner nations in the search for a more effective response to modern security challenges, as well as the beginning of a new relationship with the nations of the Western Balkans. ${ }^{30}$ During a visit to Croatia in July 2007, the Secretary-General of NATO, Jaap de Hoop Scheffer, said in Dubrovnik: "The beginnings of the post-Cold War transformation of NATO are exactly here, in Southeastern Europe. The fall of Yugoslavia forced NATO to take over the role it had never considered before - that is, crisis management and peace keeping. NATO's engagement in the Balkans shaped the evolution of NATO itself in a critical way, maybe more that any other foreign event." ${ }^{31}$

28 The task of resolving the border issue of the Prevlaka peninsula with Croatia has been delegated to the Court of Justice in The Hague, while at the same time a mixed commission of the Montenegrin and Croatian governments has been established to determine the border on the peninsula. This commission will develop the legal framework for solving this problem. At the same time, the parliaments of the two states will bind themselves, through declarations, to respect the court decision. Until the definitive solution has been found, the previously accepted Protocol on the Temporary Regime on Prevlaka is still in force.

29 The exact data about the countries with whom an agreement on cooperation has been signed can be found in point 1.2 of the Report on the Implementation of IPAP (July 2009).

30 Anton Grizold and Lidija Čehulić, International Security and NATO in the New World Order (Zagreb: Faculty of Political Science, 2006), 57.

31 NATO Secretary-General Jaap de Hoop Scheffer, "Europe's New South," introductory speech at the "Croatia Summit 2007," Dubrovnik, 6 July 2007. 
In order to overcome all of the obstacles and prejudices characteristic of the Western Balkans region, several initiatives in Southeastern Europe have been initiated with the encouragement of the EU, the UN, NATO, and the U.S. ${ }^{32}$ Among these various efforts, some stand out as particularly significant for security and stability in the region:

- South-East Europe Cooperation Process (SEECP): Montenegro first attended the SEECP meetings as an observer, and became a full member on 10 May 2007

- South-East Europe Initiative (SEEI): Montenegro succeeded Serbia and Montenegro as a member of SEEI, after its declaration of independence in 2006

- U.S.-Adriatic Charter: Montenegro was granted observer status under the U.S.-Adriatic Charter on 3 December 2006, and it became a full member of this initiative, along with Bosnia and Herzegovina, on 4 December $2008^{33}$

- South Eastern Defense Ministerial Process (SEDM): Montenegro has been a full member of the SEDM process since 21 October 2009

- Southeast Europe Clearinghouse (SEEC): Montenegro has been a full member of the SEEC since November 2006

- Regional Arms Control Verification and Implementation Assistance Centre (RACVIAC): Montenegro has been a full member of RACVIAC since 21 March 2007

- Regional Center for the Combating of Cross-border Crime: Based on the Government Regulation on Sending Police Representatives Abroad, the first representative of the Police Directorate of Montenegro was sent to this Center in November 2009. At the same time, one representative of the Police Directorate was sent to INTERPOL Headquarters in Lyon.

Besides the initiative mentioned above, which are focused on cooperation in Southeastern Europe, Montenegro is also involved in several other very important initiatives that are broader in their regional scope:

- Central European Initiative (CEI): Since declaring independence in 2006, Montenegro has been a full-fledged member of the CEI; it took over the presidency of this initiative on 1 January 2010

32 Anton Grizold, Security and Cooperation in Southeastern Europe (Ljubljana: Security Studies Collection, Faculty of Social Sciences, 2003).

33 On 23 April 2009, a meeting of the Adriatic Charter was held at the level of political directors of ministries of foreign affairs of the member countries. Montenegro participated in the work of the Charter as a full member for the first time on 08 May 2009, when the Minister of Foreign Affairs, Milan Roćen, participated in the meeting of ministers of foreign affairs of the member countries in Tirana. On 21 May 2009, the Chief of the General Staff of the Montenegrin Army participated in the Tenth Conference of Chiefs of General Staffs of the Adriatic Charter members in Tirana. 
- Adriatic-Ionian Initiative: Montenegro has continued to be a member of the Adriatic-Ionian Initiative after gaining independence in 2006; it will assume the presidency of this initiative on 1 June 2010

- INTERPOL: The Police Directorate of Montenegro was accepted as a full member of INTERPOL on 19 September 2006, at the general assembly meeting in Rio de Janeiro.

\section{Montenegro's Participation in Peacekeeping Missions}

In its strategic documents, Montenegro has clearly expressed its commitment to participating in international peacekeeping missions led by the Untied Nations, NATO, and the EU, in order to contribute to the preservation of peace and stability in the world. Based on a proposal from the Defense and Security Council, the Parliament of Montenegro makes all decisions about the participation of members of the Montenegrin Armed Forces in international activities and peacekeeping missions. Decisions on the participation of members of civil protection and police forces (as well as others employed by the state authorities) are made by the executive branch of the Montenegrin government.

In order to provide the necessary conditions for the practical implementation of this commitment, in October 2008 the Parliament of Montenegro adopted the Law on the Utilization of the Units of Armed Forces of Montenegro in International Forces and Participation of the Members of Civil Protection, Police and Other Employees in the State Authorities in Peace-keeping Missions and Other Activities Abroad. ${ }^{34}$ The parliament also adopted a decision on the engagement of a medical team from the armed forces of Montenegro in the UN peacekeeping mission in Afghanistan, according to the Resolution of the Security Council (No. 1833). Less than one year later, on 29 July 2009, the Parliament of Montenegro adopted a decision to send Montenegrin soldiers to participate in the international peacekeeping missions in Afghanistan, Somalia, and Liberia. $^{35}$

34 The Law on the Utilization of the Units of Armed Forces of Montenegro in International Forces and Participation of the Members of Civil Protection, Police and Other Employees in the State Authorities in Peace-keeping Missions and Other Activities Abroad, Official Gazette of Montenegro, no. 61 (13 October 2008).

35 In July 2009, the Parliament of Montenegro decided to send Montenegrin soldiers to participate in:

The UN peace mission in Liberia (UNMIL), in which up to two members of the Armed Forces of Montenegro will participate on a rotating basis (this represents the continuation of involvement begun by Serbia and Montenegro);

The International Security Assistance Force (ISAF) in Afghanistan, in which a unit of forty members of the Armed Forces of Montenegro will take part; this unit consists of infantry, medical personnel, staff personnel, and a national intelligence cell;

The EU naval operation (EU NAVFOR) Atalanta, which is patrolling the waters off the coast of Somalia; up to three members of the Armed Forces of Montenegro are participating, on a rotating basis. 


\section{Military Participation in Peacekeeping Missions}

ISAF Mission in Afghanistan. The International Security Assistance Force (ISAF) was created in accordance with the conclusions of the conference held in Bonn in December 2001 after the collapse of the Taliban regime in Afghanistan. ISAF has been established as a coalition of the willing in accordance with UN Security Council Resolutions 1386,1413 and 1444 . The first ISAF operation was conducted jointly by Great Britain, Turkey, Germany, and the Netherlands in February 2003, at which time those states requested NATO support. In August of 2003, the Allies took over the responsibility for ISAF, thus solving the problem of selection of new countries that are ready and able to take over the mission every six months. This intervention represents the first NATOled operation outside of the Euro-Atlantic area. ${ }^{36}$

ISAF's primary role is to provide military assistance to the UN mission in Afghanistan (UNAMA), to aid the transitional government of Afghanistan in establishing a secure environment in Kabul and the surrounding areas, and to assist in the rebuilding of Afghanistan. Since October 2003, the UN has extended the ISAF mission's mandate to the entire territory of Afghanistan. Provincial Reconstruction Teams (PRT) have been established throughout the country; they consist of volunteers and civil experts from different functional areas to provide assistance to the Afghan government in extending its authority over the provinces and to facilitate security development in each region.

Based on the Montenegrin parliament's decision, the schedule of members of the Armed Forces of Montenegro participating in the ISAF mission should be as follows:

- Two staff officers will be allocated in late February 2010 to the regional command NORTH, based in Mazar-i-Sharif, with six-month rotations

- An infantry platoon of twenty-five members will be deployed in late February/early March 2010 to provide physical security for the Hungarian PRT base in Pol-e-Khomri, with six-month rotations

- One logistics staff officer will be allocated to the base together with the Infantry platoon, to be deployed at the same time

- A medical team consisting of three members (a doctor, a medical technician, and a nurse) will be allocated to the Hungarian PRT base along with the infantry platoon and the logistics officer, with six-month rotations.

EU NAVFOR Operation "Atalanta" in Somalia. With the recent upsurge of piracy and armed robberies along the Somali coast, the European Union set in motion a joint military operation of the European Union Naval Force called "EU NAVFOR Somalia, Operation Atalanta. The operation is being carried out in support of UN Security Council Resolutions 1814, 1816, 1838 and 1846 (2008), with the purpose of protecting ships used by the various aid programs at work in Somalia as well as protecting the vulnerable cargo ships and passenger liners along the Somali coast. The force is also

36 Radovan Vukadinović, Lidija Čehulić Vukadinović, and Davor Božinović, NATO EuroAtlantic Integration (Zagreb: Topical, 2007). 
intended to serve as a deterrent against those committing acts of piracy, as well as an enforcement mechanism to pursue and apprehend pirates.

The mandate for the EU NAVFOR peace operation contains the following elements:

- Provide protection to the ships used by the World Food Program, including posting an armed unit aboard such ships, especially while cruising in Somalia's territorial waters

- Provide protection for cargo ships while they are sailing in areas where the EU forces are allocated

- Control traffic in areas of Somalia's territorial waters where maritime transport is threatened

- Take all necessary measures, including the use of force, to deter, prevent, and intervene in acts of piracy and armed robbery that take place in the areas where the EU forces are located.

The EU NAVFOR consists of six frigates and three naval patrol aircraft, with a combined total of over twelve hundred deployed personnel. Parliament's decision anticipates the deployment of up to three members of the Armed Forces of Montenegro to the mission EU NAVFOR, with the possibility of rotation.

UN Mission in Liberia. Since gaining independence in 2006, Montenegro has continued its participation in the UN international peacekeeping mission in Liberia (UNMIL), which started in December 2003, while Montenegro was still a part of the Federal State of Serbia and Montenegro. To date, five members of the Armed Forces of Montenegro have taken part in this mission, while two officers are currently participating as observers. The parliament's decision to provide additional assistance to this mission anticipates the deployment of up to two members of the Armed Forces of Montenegro to UNMIL, with the possibility of rotation.

\section{Police Directorate Participation in Peacekeeping Missions}

According to the new legislation regarding the deployment of the Montenegrin military in international forces and the participation of other state employees in peacekeeping missions abroad, the Montenegrin government made a decision to send one member of the Police Directorate to participate in the peacekeeping mission on Cyprus in August $2009 .{ }^{37}$ A second member is expected to be sent in 2010.

\section{Montenegro's Future Priorities}

The reform and establishment of a robust national security sector, and especially the defense sector as its most prominent component, are important and unavoidable issues with respect to the process of Euro-Atlantic integration. ${ }^{38}$ In light of these concerns,

37 The government of Montenegro made a decision on sending members of the Police Directorate to the peace mission on Cyprus, No. 03-8965/3 (30 July 2009).

38 Ivan Mašulović, The National Security System of Montenegro (Bar: Faculty for Business Management, 2008). 
there are four factors that will have a significant influence on the future process of Euro-Atlantic integration and that deserve additional attention: the creation of an Annual National Program (ANP); participation in NATO exercises in order to get training and reach interoperability; participation in peacekeeping missions and operations led by the UN, EU, and NATO; and increasing the level of public support for joining NATO.

\section{Annual National Program}

The Membership Action Plan is implemented through annual national programs that represent specific catalogues describing the profiles and characteristics of aspirants to NATO membership in five areas: political and social; defense and military; financial; security; and legal issues. Each candidate country prepares its own Annual National Program (ANP) in all areas, which it then submits to NATO. Montenegro began working on its ANP after it was admitted to the Membership Action Plan. What this means at present for Montenegro is that the nation will soon begin consultations with NATO regarding the creation of its program, since it is expected to begin more intensive work on its first ANP by April 2010. The first ANP should be completed by September 2010, when its implementation would begin (lasting until September 2011).

\section{Participation in NATO Training Exercise}

As part of the security sector reform process, Montenegro is working to achieve the required level of interoperability of its forces and equipment with NATO forces and equipment as soon as possible. Interoperability is best achieved through continuous training, which contributes to the increase of the proficiency level of Montenegro's military personnel, as well as to the operative, material, and administrative standardization of forces. Participating in joint exercises in order to acquire training with NATO structures is one of the most effective ways of reaching and verifying the necessary level of interoperability.

Montenegro has participated in six NATO exercises since joining the Partnership for Peace: Cooperative Marlin ${ }^{39}$; Cooperative Mako ${ }^{40}$; Cooperative Longbow ${ }^{41}$; Coop-

39 The command-staff exercise Cooperative Marlin is intended to: increase the interoperability and adoption of standardized procedures in anti-submarine warfare, familiarize participants with NATO organization and C2 (command and control); and build understanding of the philosophy and doctrine of anti-submarine warfare in NATO.

40 The annual maritime exercise Cooperative Mako, a naval NATO/PfP exercise, is intended to improve the standards in interoperability between the maritime forces of Partners and NATO members through joint participation in and conduct of maritime operations in CRO (Crisis Response Operation). It is designed to be complementary to the command-staff exercise Cooperative Marlin, which represents the preparation phase of the overall activity. The exercise involves: Non-Combat Evacuation (NEO); maritime operations-port or waterways blockade (MIO); counter-terrorist tasks; humanitarian aid tasks; enforcing an embargo; and providing security in areas of strategic importance. 
erative Lancer ${ }^{42}$; Combined Endeavor" ${ }^{\text {"33 }}$; and MEDCEUR. ${ }^{44}$ In 2010, Montenegro will continue to participate in the aforementioned exercises, while three NATO exercises will be held in Montenegro: Cooperative Marlin, Cooperative Mako, and MEDCEUR. This will be a good opportunity to gauge the progress of the implementation of the agreements signed between NATO and Montenegro in Montenegrin territory, and to assess the level of interoperability that has been achieved in all state structures involved in carrying out the exercises.

\section{Participation in Peace Missions and Operations Led by the EU, UN, and NATO}

One of the more important goals for Montenegro as part of the Euro-Atlantic integration process is making a significant contribution to international peace and stability. Apart from its positive role in improving the security in the Western Balkans, Montenegro is ready to participate in peace missions led by the UN, EU and NATO in other parts of the world, in accordance with its capabilities.

A specialized U.S. company, MPRI (Military Professional Resources Incorporated), which already has a history of providing this kind of training in many parts of the world, has been hired to engage in direct preparation and training of two infantry platoons of the Montenegrin Army. The goal of this training is to provide practical preparation for Montenegrin soldiers to ready them for the specific conditions they will encounter in providing physical security at the base of the Hungarian PRT in Pol-eKhomri, in northern Afghanistan.

41 Cooperative Longbow is a simulation command exercise that provides for the training of multinational army brigade staff personnel. The key tasks involve the protection of sensitive points and the establishment of a secure environment, conducting non-combat evacuation operations, and engaging in counter-terrorist combat in order to prevent the potential destabilization of a certain country.

42 Cooperative Lancer is a field command exercise that provides for the training of multinational army brigade staff personnel in crisis situation operations. The key tasks involve the protection of sensitive points and the establishment of a secure environment, conducting non-combat evacuation operations, and engaging in counter-terrorist combat in order to prevent the potential destabilization of a certain country.

43 Combined Endeavor represents training in NATO procedures regarding information and telecommunication systems and the increase in the level of interoperability between PfP and NATO countries. Its focus is on practicing tactical-technical and procedural solutions, in the spirit of PfP C4 integration (command, control, computers and communication).

44 The MEDCEUR exercise provides for the development of interoperability of Partnership for Peace countries, as well as for cooperation in the medical treatment of victims of different natural catastrophes. The exercise allows for the demonstration of the ways that different states at the same level of medical care provide medical treatment and professional help, and assists in building interoperability among different medical teams (general practitioners, specialists, surgeons, radiologists, bio-chemists, ORL, ophthalmologists). The exercise also involves a series of lectures in the area of modern procedures in cardiovascular and trauma care for patients, as well as in the area of contagious diseases, with sixty-four lessons of theory and practical training overall. 
Apart from the preparations for the ISAF operation, a course for UN military observers "BALMOC 1/09" (Balkan Military Observer Course), organized by the Finnish Centre for Training (FINCENT), was held from 14 September-1 October 2009. Sixty representatives of the armed forces of twelve countries participated (Albania, Bosnia and Herzegovina, Croatia, Denmark, Estonia, Finland, Latvia, Lithuania, Macedonia, Norway, Serbia, and Sweden). In order to further improve the preparedness of its security force personnel for participation in peace missions, in the near future Montenegro will try to intensify and improve the level of cooperation with partnership training centers in the region and beyond.

\section{Increasing Public Support for Joining NATO}

In order to inform the Montenegrin public about the nation's plans with respect to Euro-Atlantic integration in an organized way and in prompt fashion, in October 2007 the Montenegrin government adopted a communication strategy specifically regarding Euro-Atlantic integration. For its effective implementation throughout all tiers of society, the government formed a coordination team with representatives from the ministries of defense, interior, education and science, culture and sports, and finance, as well as the Bureau for Public Relations. The coordinator of the team is the Chief of Cabinet of the Prime Minister. In order to deploy the communication strategy in phases, the coordination team has made suggestions for six-month action plans.

To ensure full transparency in their work, the coordination team adopted the text of a Memorandum on Cooperation with the NGOs, which has been signed by representatives from non-governmental organizations active in Montenegro. These include the Association of Young Journalists, the Alfa Center, the Center for Democratic Transition, the Euro-Atlantic Club, the Nansen Dialogue Center, the Youth Movement for Euro-Atlantic Integration, the Media Institute, the Center for Euro-Atlantic Integrations, and the Spona (Connection) from Berane, which coordinates the work of fortytwo smaller NGOs from municipalities from the northern part of Montenegro (primarily from Plav, Andrijevica, Rožaje, and Berane).

Unlike the high level of public support for integration into the EU-which is, according to most surveys, over 70 percent-and despite all the activities that have been undertaken to inform and explain to the people of Montenegro the importance of integration into the Euro-Atlantic security community, the level of public support is still insufficient. According to a survey conducted by the European Movement for Montenegro in December 2008, 41.3 percent of Montenegrin citizens support the prospect of Montenegro's membership in NATO, while 34 percent are against. Those who are against NATO membership identify as the main reason for their disapproval the potential deployment of Montenegrin soldiers in peace operations, while 22 percent say their resistance is due to NATO strikes on Serbia in 1999.

According to surveys conducted by the U.S.-based National Democratic Institute (NDI), also from December 2008, 54 percent of Montenegrin citizens are against joining NATO, because they believe that membership in NATO will force the nation to participate in wars that are fought in the interests of others. According to the same survey, 46 percent of the public thinks that Montenegro should join NATO, and mention 
that the main advantage is that NATO membership would represent a step forward toward EU membership, and would also make a contribution to regional stability.

According to surveys about NATO membership conducted in January 2009 by the Center for Monitoring in Podgorica (CEMI), 39.5 percent were in favor of Montenegro joining NATO, 37.9 percent were opposed, 15.7 percent had no preference, and 7 percent were not sure. When asked if Montenegro would benefit from NATO membership, 46.6 percent said yes, 41.1 percent thought not, while 12.2 percent had no opinion either way.

Another series of surveys carried out over the last two years by the Center for Democracy and Human rights (CEDEM) indicate that the level of support among Montenegrin citizens for joining NATO is between 30 and 35 percent. A CEDEM survey from March 2009 showed 31.2 percent in favor of joining NATO, 45.1 percent against, and 23.7 percent without any particular opinion. Surveys from June and October 2009 offered virtually identical results. ${ }^{45}$

The differences between the results from surveys conducted by different agencies reflect the instability of Montenegrin public opinion regarding the issue of NATO membership. It is important to bear in mind, however, that until Montenegro gained independence in 2006, only 30 percent of its citizens had traveled abroad (not including the former republics of Yugoslavia). Since most of those who had traveled abroad had visited the countries of the former Soviet Union, we could say that a lack of information is a very influential factor in the seeming reluctance among the Montenegrin public to enter into a relationship that might obligate Montenegro to become involved far from the familiar region of the Western Balkans. The nation's traditional connections to Russia are another significant factor. Long years of living together, along with a certain nostalgia towards Serbia, together with resentment over the NATO bombing campaign in 1999, are also factors that help explain the low levels of support for joining NATO.

As far as the positions of the political parties in Montenegro are concerned, the situation is completely reversed, which is encouraging, since it induces optimism that the attitude of the citizens will probably change in a positive direction. With the exceptions of the New Serbian Democracy party, which only earned eight seats in parliament in the March 2009 elections, and the People's Party and the Liberal Party of Montenegro (which lost their parliamentary status in the March elections), all other political parties in Montenegro have a positive attitude regarding the prospect of NATO membership.

NGOs in Montenegro also have a largely positive attitude with regard to joining NATO, and there are almost none that are conducting an organized campaign against accession to NATO membership. The Euro-Atlantic Club of Montenegro has played a special role in this area, since they have significantly influenced the creation of a favorable attitude among the citizens towards NATO through a series of informational

45 Results of the CEDEM public opinion surveys are available at www.cedem.co.me/opolls/ images/CEDEM_March09.pdf. 
and educational activities. Apart from the Euro-Atlantic Club, the Alfa Center from Nikšić, the Center for Democratic Transition from Podgorica, and Spona from Berane have played significant roles as well.

In order to more effectively inform and educate the citizens about the Euro-Atlantic integration process, a special organizational unit has been established at the Political Science Faculty in cooperation with the governmental coordination team, called the Center for Euro-Atlantic Integration. To the same end, at the University of Donja Gorica, also in Podgorica, the establishment of a NATO Information-Documentation Center is ongoing. Given the importance of generating and sustaining public support for joining NATO, this will be one of the most important priorities in the near future, and it deserves our full attention.

\section{Conclusion}

\section{NATO and the Open-Door Strategy}

It is a great boon for all of us that the "open-door" strategy is still one of the main principles on which the Alliance is based. The latest statement of the new Secretary-General of NATO, Mr. Anders Fog Rasmussen, is of great importance for Montenegro, as he clearly stated that the Western Balkan countries belong to the Alliance, and that NATO enlargement would continue.

Montenegro fully supported the Euro-Atlantic aspirations of its neighbors. The accession of Albania and Croatia to NATO were seen in Montenegro as its own success, for the progress of our neighbors represents the progress of the region as a whole. Likewise, Montenegro joins in the hope that Macedonia will soon find a solution to its well-known problems and take its place as an Alliance member as well. It is important to emphasize that the most recent NATO Summit sent a number of positive signals towards the countries of the region, and has rendered the prospect of becoming a member of NATO an open issue.

As far as the Western Balkans are concerned, but also in a wider context, the process of integration into the Euro-Atlantic security community cannot be separated from the process of integration into the EU. These two processes are mutually intermingled and bound to each other, not just because they encompass the same countries, but because the two processes are founded on the very same democratic values and principles.

\section{Montenegro}

A practical and efficient implementation of Partnership for Peace mechanisms has enabled Montenegro to very rapidly gain access to the Intensive Dialogue with NATO, and to gain the status of a candidate country by beginning the Membership Action Plan process. To further these processes, special emphasis should be placed on the following activities:

1. Contributing to the preservation of peace and stability in the world through participation in international missions and operations led by the UN, EU and NATO is a strategic priority for Montenegro on the international scene. By 
taking part in such operations, Montenegro demonstrates its readiness to assume the mantle of responsibility even in the most demanding, strategic activities undertaken by Montenegro's future allies, such as the ISAF mission in Afghanistan, in which Montenegro will take part starting in March 2010.

2. Montenegro will continue to pursue the fulfillment of its obligations stemming from IPAP, in accordance with the plan aligned with NATO.

3. Montenegro should pay special attention to maintaining good relations with its neighbors and fostering comprehensive regional cooperation. Active involvement and participation in the work of the Adriatic Charter, in all areas, represents a new opportunity for Montenegro to accomplish this key foreign policy priority. Montenegro considers the Adriatic Charter to be a firm chain linking the countries of the region that share common Euro-Atlantic goals.

Montenegro is ready to remove all the obstacles that obstruct its path towards NATO membership as soon as possible, with appropriate consultation with and assistance from NATO, neighboring countries, and other members of NATO and PfP. Therefore, receiving the invitation to participate in the Membership Action Plan confirms the results that Montenegro has already achieved in its pursuit of integration into the Euro-Atlantic community. 


\section{Bibliography}

Grizold, Anton, and Lidija Č. ehulić. International Security and NATO in the New World Order. Zagreb: Faculty of Political Science, 2006.

Grizold, Anton. Security and Cooperation in Southeastern Europe. Ljubljana: Security Studies Collection, Faculty of Social Sciences, 2003.

Mašulović, Ivan. The National Security System of Montenegro. Bar: Faculty for Business Management, 2008.

Membership Action Plan. Brussels: NATO Handbook 2006, 2006.

National Security Strategy. Official Gazette of Montenegro, no. 75/08, 2008.

Regulation on the Organization and Operation of the State Administration. Official Gazette of Montenegro, no. 54/04 (2004) and no. 43/09 (2009), 2009.

Resolution on the necessity of accelerating the process of integration of Montenegro into the European and Euro-Atlantic structures. Official Gazette of Montenegro, no. 60/08, 2008.

Scheffer, Jaap de Hoop. Europe's New South In Croatia Summit 2007. Dubrovnik: NATO Secretary-General, 2007.

Tahirovic, Mehmedin. "Montenegro and the NATO Partnership for Peace Program." Connections: The Quarterly Journal 7, no. 1 (2008): 17-45.

The Conclusion of the Government of Montenegro., 2009.

The Constitution of Montenegro. Official Gazette of Montenegro, no. 01/07, 2007.

The Declaration of the Independent Republic of Montenegro. Official Gazette of Montenegro, no. 36/06, 2006.

The Declaration on Accession to the European Union. Official Gazette of Montenegro, no. 36/05, 2005.

The Defense Strategy of Montenegro. Official Gazette of Montenegro, no. 79/08, 2008.

The Law on Defense. Official Gazette of Montenegro, no. 47/07, 2007.

The Law on Protection of Classified Information. Official Gazette of Montenegro, no 14/08, 2008.

The Law on the Military of Montenegro. Official Gazette of Montenegro, no. 47/07, 2007.

The Law on the Utilization of the Units of Armed Forces of Montenegro in International Forces and Participation of the Members of Civil Protection, Police and Other Employees in the State Authorities in Peace-keeping Missions and Other Activities Abroad. Official Gazette of Montenegro, no. 61, 2008.

Vukadinovic, Radovan, Lidija Čehulić Vukadinović, and Davor Božinović. NATO Euro-Atlantic Integration. Zagreb: Topical, 2007. 